\title{
Translation Procedure Used in Translating Banking Term in Legal Documents of BCA
}

\author{
Istihayyu Buansari $^{1,}$ Ahmad Supriatno ${ }^{2}$ Maulani Pangestu ${ }^{3}$ \\ ${ }^{1,3}$ Universitas Bina Sarana Informatika \\ email: $\underline{\text { istihayyu.iyb@ bsi.ac.id }}^{1}$, $\underline{\text { maulani.mpu@bsi.ac.id }}^{3}$ \\ ${ }^{2}$ PT. Benesse Indonesia \\ email: ahmad@ benesse-id.com ${ }^{2}$
}

\begin{tabular}{ccc}
\hline Diterima & Direvisi & Disetujui \\
$29-06-2020$ & $31-08-2020$ & $13-09-2020$ \\
\hline
\end{tabular}

\begin{abstract}
Banking terminology is specialized language which is quite distinct from the translation of general texts. Specialized translation is meant to improve the communication among experts of a domain and to contribute to the distribution of knowledge across language boundaries. In this research the writer tried to use banking document as the corpus in finding banking terminology. The main focus was the translation of banking terminology in Financial Review of BCA into Indonesian, translated by Anang Fachruddin, a sworn translator having its official address in Kalibata. This document is selected to be the subject of this corpus, since there is a number of banking terminology found there. Conducted as a descriptive analytical study, this research was aimed (1) Identifying the procedures applied in translating banking terminology in legal documents, and (2) to find out to what extent the use of procedure effect the meaning. The writer chooses Newmark theory of translation procedure since it contains more detail information and explanation. From the total number of 98 terminologies occurred in Financial Review of BCA, the writer only found ten out of eighteen procedures of Newmark applied in translating banking terminology in legal document. The procedures are; (1) Literal Translation (34.02\%), (2) Transference (26.5\%), (3) Naturalization (8.1\%), (4) Functional Equivalent (3.0\%), (5) Descriptive Equivalent (10.2\%), (6) Synonym (3.0\%), (7) Shift or Transposition (4.0\%), (8) Reduction and Expansion (5.1\%), (9) Equivalence and Adaptation (1.0\%), (10) Couplets (2.0\%). Overall, the Indonesian translated version of banking terminologies did not changed the meaning of the source text.
\end{abstract}

Keywords: Translation, Sworn Translation, Banking, Legal Document.

Abstrak: Istilah perbankan merupakan bagian dari bahasa khusus yang bentuknya berbeda dengan nas umum. Penerjemahan khusus bertujuan untuk meningkatkan komunikasi diantara ahli dan berperan serta dalam memberikan pengetahuan melewati batasan bahasa. Dalam penelitian ini penulis berusaha menggunakan dokumen perbankan sebagai korpus penulisan dalam menemukan istilah perbankan. Fokus utamanya adalah penerjemahan istilah perbankan dalam Tinjauan Keuangan Bank Central Asia ke dalam bahasa Indonesia, diterjemahkan oleh Anang Fachruddin, seorang penerjemah tersumpah berkantor di daerah Kalibata. Dokumen ini dipilih menjadi korpus penulisan karena ada banyak istilah perbankan yang ditemukan disana. Dilaksanakan sebagai penelitian Deskriptif Analisis, penelitian ini bertujuan untuk: (1) mengenali prosedur yang dipakai dalam menerjemahkan istilah perbankan dalam dokumen legal dan (2) mencari tahu sampai sejauh mana penggunaan prosedur diatas mempengaruhi makna. Penulis menggunakan teori Peter Newmark mengenai prosedur penerjemahan karena teori tersebut berisikan lebih bnyak informasi dan penjelasan. Dari 98 istilah yang ditemukan dalam Tinjauan Keuangan Bank Central Asia, penulis hanya menemukan sepuluh dari delapan belas prosedur Peter Newmark yang diterapkan dalam menerjemahkan istilah perbankan di dokumen legal. Prosedur tersebut adalah; (1) Literal Translation (34.02\%), (2) Transference (26.5\%), (3) Naturalization (8.1\%), (4) Functional Equivalent (3.0\%), (5) Descriptive Equivalent (10.2\%), (6) Synonym (3.0\%), (7) Shift atau Transposition (4.0\%), (8) Reduction dan Expansion (5.1\%), (9) Equivalence dan Adaptation (1.0\%), (10) Couplets $(2.0 \%)$. Secara keseluruhan, istilah perbankan yang diterjemahan ke bahasa indonesia tidak merubah makna dari bahasa sumber atau bahasa Inggris.

Kata Kunci: Penerjemahan, Penerjemahan Tersumpah, Perbankan, Dokumen Legal

\section{INTRODUCTION}

The banking industry is in a much healthier place now than it was after the financial crisis of 2008. Total global assets climbed to $\$ 124$ trillion in
2018, according to The Banker's Top 1000 World Banks Ranking for 2018. With so much money to manage, major banks such as JPMorgan Chase, Bank of America, Wells Fargo, and more are 
releasing new features to attract new customers and retain their existing ones. On top of that, startups and neobanks with disruptive technologies are breaking into the scene, and traditional banks are either competing with them or merging with them to improve their service. So let's dive into the banking industry, the challenges it faces, and the road ahead.

Furthermore, an enormous growth of the area of translation has built this world as a dimension where boundaries are no longer be existed. It is a dimension where human interaction inter-cultures become a daily activity and all of the human being will inevitably have to deal with it. And every interaction leads us to a new concept of message given in form of oral or written text. (Amalia, 2006) states that it is a process of transferring a message from one language to another, translation can play a very decisive role in communication. Translation, in deed, is a human activity, which enables human beings to exchange their ideas and thoughts regardless of the different language they used. Without translation, there are no message sent and the result are that the information existed intercultural are no longer be expressed.

The main purpose of every translation activity is to create a legitimate translation work. Every translation work is intended to help overcome the communication gap, which exist between the writer of the source language and the reader of the target language (Widyastuti et al., 2017). Therefore, the success of a translation work largely depends on its success in serving as a communication bridge between two different language backgrounds. Naturally, translators want to do justice to their own art by accommodating the literary demands on language of the original text. Translator finds themselves constantly restricted by those language boundaries and by pressing necessity to remain, as closely as possible, faithful to the original text. (Nida 1914-2011, 1969)

(Kela, 2008) that "translation is an act of communication which attempts to relay, across cultural and linguistic boundaries, another act of communication (which may have been intended for different purposes and different readers/hearers)." Through translation, boundaries that separate people are eliminated. Messages or ideas that are presented in a certain language can be translated into another language accurately and fluently.

Nevertheless, some problems may occur if it deals with terminology and culture difference as well as the structure.

Such problem emerges because every country has different legal system. In translating legal translation a good English mastery is not enough you must also have a good understanding about the prevailing law system.

The system in legal text affects the successful translation which involves competency of three separate areas. Such area, based on (David Crystal, 2016) are, first; a basic knowledge of the legal systems, both of the source as well as of the target languages; second, familiarity with the relevant terminology; and third, competency in the specific legal writing style of the target language. Without these competencies, the translator's rendition will be word-for-word translation, which is incomprehensible.

(The_Bilingual_LSP_Dictionary, n.d.) stated "the legal system of the source text is structured in a way that suits that culture and this is reflected in the legal language; similarly, the target text is to be read by someone who is familiar with another legal system and its language. Most forms of legal writing, and contracts in particular, seek to establish clearly defined rights and duties for certain individuals. It is essential to ensure precise correspondence of these rights and duties in the source text and in the translation."

The focus of this study is not only discusses techniques used in translating banking terminology in legal documents from English into Indonesian but also how the English banking terminology is translated into Indonesian language. Beside, this study also focuses on Financial Review of Bank Central Asia (BCA).

Because of time constrains, in the is study the writers would focus only on the following questions:

1. What are the procedures applied in translating banking terminology in legal documents of BCA Financial Review?

2. To what extent that the use of procedure effect the meaning in the Financial Review of BCA?

\section{A. Translation Definition}

As history been written, a number of different theories and opinions about the essence of translation have been existe $d$. According to Newmark (Schäffner, 1993) "translation is a craft consists of an attempt to replace a written message and/or statement in one language by the same message and/or statement into another language". It means that translation should convey exactly the same message to Target Language (TL) as implied in Source Language (SL). Newmark then added that, "A translation is normally written and intended for a target language reader- even if the 
source language text was written for no reader at all, for nothing but its author's pleasure. The translator has to assist his reader." He also states that "'foreign' communities have their own language structures and their own cultures, 'foreign' individuals have their own way of thinking and therefore of expressing themselves, but all these can be explained, and as a last resort the explanation is the translation." Such statements are the reason why translators have to understand a culture in general.

(Hatim \& Munday, 2013), then added that "translation is a process of conveying messages across linguistic and cultural barriers." It means that the process of translation connects two languages in order to deliver the meaning from one language to another.

\section{B. Translation Process}

The process of translation is generally tries to convey and reproduce the meaning of a text with very different form of language. (Verity \& Larson, 1986) describe translation as the process of studying the lexicon, the grammatical structure and the communication situation of the source language text, analyzing it in order to determine the meaning, and the reconstructing the same meaning using the natural forms of the receptor language. She explains that there is substitution in the form of the source language into the form changing of form, and never meaning. It can be seen from the overview of the translation task below.

\section{SOURCE LANGUAGE RECEPTOR LANGUAGE}
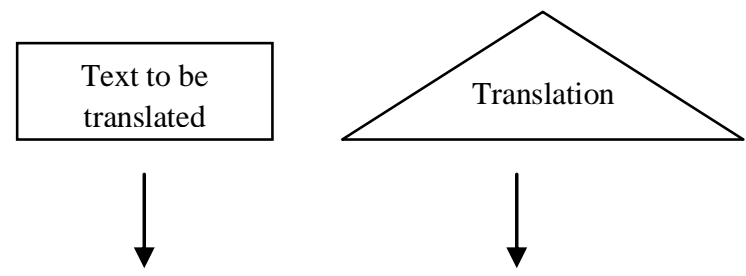

Discover the meaning

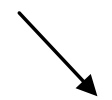

Re-express the meaning

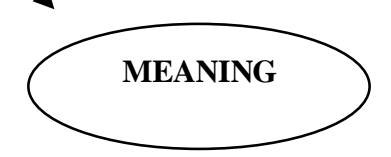

Figure 1. The Process of Translation (Verity \& Larson, 1986)

From above picture, translations means the lexicon, the grammatical structures of the SL, communication situation, and the cultural context of the SL. it proves that the response of the receptor to the translated message is the most important thing in translation. The response must be the same as the way in which the original receptors re-acted the message when the message was given in the original setting.

(Nida et al., 1975). From the two theories, first is theory in which the translator is loyal to the source language, and tries to optimally preserve the original meaning as well as the expression and style of the writer of the source language, which involve word order or sentence structure; while, the second is theory in which the translator is loyal to the readers of the target language. In this theory, the translator tries to reproduce the meaning or the message of the source language into words in the target language that are easy to understand.

\section{Translation Procedures}

Larson mentioned two kinds of translation that are used by translator in making adequate translation. They are Literal and Idiomatic translations (Verity \& Larson, 1986) Literal translation is a translation in which a translator pays more attention on the structure of the language while idiomatic translation is focus on the meaning without pays much attention to the structure of the source language. Such types of translation have the same intention, that is to produce qualified and a good translation. This activity may complicate us, since translation is a quite frustrating activity.

Hereinabove explanation shows the analysis of strategies used by a translator in translating document. The translator then will obtained similar equivalence between ST and the TT from the borrowing of foreign words that have been used internationally. Translator may apply visual translation and the written translation in SL without ignored to the he spelling. This procedure can be applied in translating legal document into Indonesian.

\section{Legal Documents}

Legal systems of L1 and L2 are likely to be wide apart, therefore the translation of legal documents, such as draft bills, laws, regulations, contracts, appeals, business documents, testimonials, certificates, licenses, international legislation, etc. calls for the knowledge of the legal system in both countries.

As noted by (Baker, 2001), that "In either case they need to become aware of the stylistic differences of L1 and L2 too, such as the use of no punctuation in agreements in English and the extremely long passages and sentences. Also, the use of various old-fashion phrases and turns and the TOA, and the definition of terms, to mention a few. (Or in Hungarian for instance, the requirement for a 
patent claim to consist of a single run-away sentence)." It means that adequate collocations and contextual references are highly required to make such work.

\section{E. Legal Translation}

Legal translation is the translation of texts within the field of law. As law is a culturedependent subject field, legal translation is not a simple task. Only professional translators specializing in legal translation should translate legal documents and scholarly writings. The mistranslation of a passage in a contract, for example, could lead to lawsuit and loss of money. When translating a text within the field of law, the translator should keep the following in mind. The legal system of the source text is structured in a way that suits that culture and this is reflected in the legal language; similarly, the target text is to be read by someone who is familiar with another legal system and its language. "Most forms of legal writing, and contracts in particular, seek to establish clearly defined rights and duties for certain individuals. It is essential to ensure precise correspondence of these rights and duties in the source text and in the translation." (Šarcevic, 1999)

\section{F. Definition of Terminology}

Based on (Cain, 2009) term or terminology is ' $a$ word, expression used in relation to a particular subject, often to describe something official or technical.' The word term refers to either a word unit or time unit with specified boundaries or limits. In terminology ("Merriam-Webster's Collegiate Dictionary," 2004), a term is 'a word, word pair, word group, that is used in specific context for a specific meaning.'

Based on ("Merriam-Webster's Collegiate Dictionary," 2004) terminology; 1. The vocabulary of technical terms used in a particular field, subject, science, or art; nomenclature. 2. The study of nomenclature. It means that terminology is specialized words and expressions relating to a particular subject.

A term is a lexical unit which creates a concept within a particular area. The recognition of terms is a task which requires complex cognitive abilities. A terminologist identifies terms because they understands the lexical and grammatical structure of a language, but most of all because they understands its semantic organization and able to map concepts into words.

\section{G. Terms and Words}

In terminology theory the way in which the meaning is structured follows a different interpretation from the one presented in the traditional semantic triangle of C.K. Ogden and I.A. Richards (figure 2.3). The semantic triangle claims that meaning is essentially a threefold relationship between linguistic forms (symbol), concepts (thought of reference), and referents (objects identified by means of word or expression) (David Crystal, 2016)

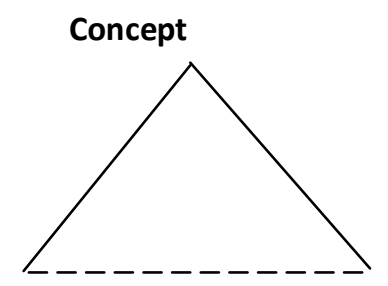

\section{Symbol Referent}

Figure 2. Ogden and Richards' semantic triangle.

The dashed base line indicates that symbol and referent are not related.

The semantic triangle was proposed by (McElvenny, 2013) in order to illustrate that there is no relevant relation between the symbol and the referent, that they are not directly connected. They did not intended to illustrate linguistic phenomena like polysemy (i.e. one expression form can refer to more than one concept form) and synonymy (i.e. one content form can be represented by two expression forms). "In terminology, however, it is very important to identify these two types of relationships between words in order to achieve context independency of words." (Niederbäumer, 2000)

\section{H. Term Formation}

(Ilha Do Desterro 28, 1992, Pp 169-170, 1992) defines term formation as the process of naming the concept required by a particular domain (25). He adds that term formation differs from general word formation "by its greater awareness of pre-existing patterns and models and its social responsibility for facilitating communication and the transmission of knowledge." (25) By means of the repeated act of creating new terms and of regulating existing terminology, a certain consistency of designation is achieved (25). Terms are on the whole less arbitrary and more consciously motivated and transparent than general words (27). Language for Special Purpose (LSP).

These reflections make evident that the wide-spread opinion that special vocabulary is mostly constituted by Latin, Greek, and nowadays English based terms is misleading. New 
terminology is not only created by importing foreign vocabulary, but new terms are also formed by employing other methods. The major distinction made in term formation is primary versus secondary term formation (Ilha Do Desterro 28, 1992, $\mathrm{Pp}$ 169-170, 1992) "Primary term formation is the process of terminology creation that accompanies concept formation" (27) as a result of any kind of innovation. Thus, primary term formation takes place in a scientific environment, and there is no direct linguistic precedent of the new term created. "Secondary term formation is the process of creating a new term for an existing concept" (27). This occurs when a designation is changed as the result of terminology revision. In German banking terminology for example, the term Mitarbeiteraktie 'employee share' has substituted the older form Belegschaftsaktie. Secondary term formation is also involved when concepts are transferred among linguistic communities. When speaking of derivatives for example, the term swap is frequently used in German compounds (Währungsswap 'currency swap', Zinssatzswap 'interest rate swap', Devisenswap 'foreign exchange swap', Schuldenswap 'debt-for-equity swap', etc.).

The process of primary and secondary term formation is carried out by three different methods (arranged in this way by (Ilha Do Desterro 28, 1992, Pp 169-170, 1992) - the use of existing resources (secondary term formation) - the modification of existing resources (secondary term formation) - the creation of new linguistic entities (primary term formation). These three methods are employed in general word formation as well. However, while in general language the creation of new words is a spontaneous process, in terminology the formation of new terms is always motivated (Niederbäumer, 2000). New terms are formed because particular circumstances require them. As will be shown later in this thesis, in German banking terminology existing lexical units are usually combined into new terms. This explains the fact that terms are in most cases compounds consisting of two or more stem words.

\section{Terminology in Specialized Translation}

Translation of specialized language is quite distinct from the translation of general texts. In general translation problems frequently encountered are whether it is better to translate literally of freely, how to preserve rhyme and rhythm of the source language in the target language, or how to deal with phenomena like word plays and proverbial sayings. These questions are not the main problem of specialized translation. Specialized translation is meant to improve the communication among experts of an area and to contribute to the distribution of knowledge across language boundaries. "The specialized translator is responsible for transferring information among experts of various speech communities" (Nida et al., 1975). The need for international communication in economy, politics, science, technical fields and more will continue to increase the necessity of specialized translations.

The major problem encountered in specialized texts is the terminology, which requires specific concepts from foreign languages to be transferred into one's mother tongue. Before starting to translate, the translator must become familiar with the terminology of a language. To find the best equivalents to the terms in question is often a timeconsuming task even for a skilled translator. Translators are not free to define unknown terms which may be too specialized to occur in a dictionary. "They have to search in previously translated documents, on the internet, or contact domain specialists. Studies show that a translator needs $40 \%$ of the working time for inquiries on unknown terminology" (Stellbrink 1988:203 retrieved from http://www.exampletranslation.htm).

No matter how well-educated a translator is, if working in a special field there will always be gaps in his/her knowledge of term equivalents. The specialist translator will constantly be faced with new terms because specialized language tends to be productive in this regard. At the same time, translation services work on a time-saving basis and in order to remain competitive little time should be spent on inquiries of unknown terms.

One of the crucial requirements for delivering high-quality translations of texts is the systematic approach to domain-specific terminology. For this task, modern language services have their own terminology centers and it is the responsibility of the terminologists to supply the professional translator with relevant terms. A terminology centre makes inquiries on special terms in several languages and provides terminology data bases (Stellbrink 1988:203).

\section{J. Definition of Banking}

Based on (Niederbäumer, 2000), banking are (1) engaging in the business of keeping money for savings and checking accounts or for exchange or for issuing loans and credit etc. finance - the management of money and credit and banking and investments right of offset - (banking) the legal right of a bank to seize deposited funds to cover a loan that is in default. (2) banking - transacting business with a bank; depositing or withdrawing funds or requesting a loan etc. finance - the commercial activity of providing funds and capital home banking - banking in which transactions are conducted by means of electronic communication (via telephone or computer), or (3) an organization, 
usually a corporation, chartered by a state or federal government, which does most or all of the following: receives demand deposits and time deposits, honors instruments drawn on them, and pays interest on them; discount notes, makes loans, and invests in securities; collects checks, drafts, and notes; certifies depositor's checks; and issues drafts and cashier's checks.

\section{METHOD}

Banking terms are words, phrases, or expression used in banking communication, in relation to a particular subject to describe something official. They are guided by rules of science and used in specific contexts for a specific meaning. Banking terms, in this matter, the terms that used in Articles of Association, Financial Statement, Audit Report, Consolidated Financial Review, Annual Report, etc. The characteristics of the terms are logic and precise. They are rarely containing cultural expression but they can consist of specialized items, abbreviations and formulae. Banking terms occurred mostly in Financial Review of Bank Central Asia is in English. In order to identify what kind of words or phrases belong to banking terms, any terms found were checked in dictionary of banking.

To analyze the data, the writer use the theory of translation from Peter Newmark which stated that translation is the attempt to replace a written message and/or statement in one language by the same message and/or statement in another language.

Based on Pedoman Umum Pembentukan Istilah, there are three categories the banking terms are translated into Indonesian. They can be translated into Indonesian language vocabulary, family-language, and foreign language vocabulary, in this case loan word. The term can be analyzed by observing what kind of vocabulary, as the source of terms. The priority in term formation is (1) commonly used Indonesian word, (2) uncommonly used Indonesian word, (3) commonly used family word, (4) uncommonly used family word, (5) English word, (6) other foreign language word, and (7) the best option among one to six. The writer will use dictionary of the banking terms and Kamus Besar Bahasa Indonesia.

From the explanation above, there are steps that applied in his study. First, is reading the source text which is Financial Review of Bank Central Asia. Second, analyzing the techniques used in translating banking term in legal documents by comparing the source text with the target text and classifying the data based on translation procedures on Newmark's theory are the next step. Third, having analyzed the data, then, the description and interpretation concerning the result of the study.

The source of the data used in this research is the original English Financial Review of Bank Central Asia, that were taken from Anang \& Partners Translation Bureau and the Indonesian translated version of Tinjauan Keuangan Bank Central Asia translated by Anang Fachruddin, a sworn translator, having its office in Kalibata. The total pages of Indonesian translation are eighty seven pages. And the total pages of English version are eighty seven pages. The term obtained will be sort out and not be the subject of the analysis twice.

The object is to analyze banking terms in the original Financial Review of Bank Central Asia, its translated version, and the procedure applied in translating them. In order to identify the words belonging to banking terms, the writer referred to the dictionary of banking terms and used the characteristic of banking terms, such as (1) words derived from Latin, (2) no figurative language attached, and (3) may contain specialized terminology. The banking terms could be a word, phrase, in form of units of weight and measurement such as act, law or the provisions.

\section{FINDINGS AND DISCUSSION}

The data in this research is English legal terminology along with its Indonesian translated version, the Financial Review of Bank Central Asia. The text was obtained from A\&P TRANSLATION BUREAU, a translation bureau having its official address in Kalibata, translated by a sworn translator, Anang Fachruddin. The data input were taken after the writer determining whether a certain words or phrases belong to word or terminology using the theory of Sager, he states that "The primary objects of terminology, the terms, are perceived as symbols which represent concepts. Concepts must therefore be created and come to exist before terms can be formed to represent them." (Sager 1990:22). A term is a lexical unit which creates a concept within a particular area. The recognition of terms is a task which requires complex cognitive abilities. A terminologist identifies terms because they understands the lexical and grammatical structure of a language, but most of all because they understands its semantic organization and able to map concepts into words.

This research analyzes how the banking terminologies in legal document are translated into Indonesian and what techniques occur most. After thoroughly observing all of the chapters in Financial Review of Bank Central Asia, the writer 
found ninety eight banking terminologies in eighty seven pages. The terms were classified into eighteen categories based on the procedure of translation of Peter Newmark. From the categories, there are only ten (10) procedures applied in the Financial Review of Bank Central Asia.

The data is as follows; (1) Literal Translation (34.02\%), (2) Transference (26.5\%), (3) Naturalization $(8.1 \%)$, (4) Cultural Equivalent (0\%), (5) Functional Equivalent (3.0\%), (6) Descriptive Equivalent (10.2\%), (7) Synonym (3.0\%), (8) Through Translation (0\%), (9) Shift or Transposition (4.0\%), (10) Modulation (.0\%), (11) Recognized Translation (0\%), (12) Translation Label (0\%), (13) Compensation (0\%), (14) Reduction and Expansion (5.1\%, (15) Paraphrase (0\%), (16) Equivalence and Adaptation (1.0\%), (17) Couplets $(2.0 \%),(18)$ Notes, additions, glosses $(0 \%)$.

Table 1. Procedures in Translating Banking Terms

\begin{tabular}{|c|c|c|c|}
\hline No. & $\begin{array}{l}\text { Translation } \\
\text { Procedure }\end{array}$ & Amount & Percentage \\
\hline 1. & $\begin{array}{l}\text { Literal } \\
\text { Translation }\end{array}$ & 35 & $34.02 \%$ \\
\hline 2. & Transference & 27 & $26.5 \%$ \\
\hline 3. & Naturalization & 8 & $8.1 \%$ \\
\hline 4. & $\begin{array}{l}\text { Cultural } \\
\text { Equivalent }\end{array}$ & 0 & $0 \%$ \\
\hline 5. & $\begin{array}{l}\text { Functional } \\
\text { Equivalent }\end{array}$ & 3 & $3.0 \%$ \\
\hline 6. & $\begin{array}{l}\text { Descriptive } \\
\text { Equivalent }\end{array}$ & 10 & $10.2 \%$ \\
\hline 7. & Synonym & 3 & $3.0 \%$ \\
\hline 8. & $\begin{array}{l}\text { Through } \\
\text { Translation }\end{array}$ & 0 & $0 \%$ \\
\hline 9. & $\begin{array}{l}\text { Shift or } \\
\text { Transposition }\end{array}$ & 4 & $4.0 \%$ \\
\hline 10. & Modulation & 0 & $0 \%$ \\
\hline 11. & $\begin{array}{l}\text { Recognized } \\
\text { Translation }\end{array}$ & 0 & $0 \%$ \\
\hline 12. & $\begin{array}{l}\text { Translation } \\
\text { Label }\end{array}$ & 0 & $0 \%$ \\
\hline 13. & Compensation & 0 & $0 \%$ \\
\hline 14. & $\begin{array}{l}\text { Reduction and } \\
\text { Expansion }\end{array}$ & 5 & $5.1 \%$ \\
\hline 15. & Paraphrase & 0 & $0 \%$ \\
\hline 16. & $\begin{array}{l}\text { Equivalence } \\
\text { and Adaptation }\end{array}$ & 1 & $1.0 \%$ \\
\hline 17. & Couplets & 2 & $2.0 \%$ \\
\hline 18. & $\begin{array}{l}\text { Notes, } \\
\text { additions, } \\
\text { glosses. }\end{array}$ & 0 & $0 \%$ \\
\hline \multicolumn{2}{|c|}{ TOTAL } & 98 & $100 \%$ \\
\hline
\end{tabular}

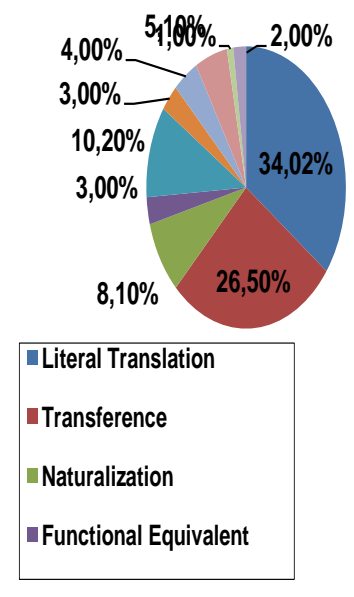

Picture 1. Procedure of Translation Banking Terms

\section{A. Literal Translation}

Table 2. Literal Translation

\begin{tabular}{|l|l|}
\hline English (Source Text) & $\begin{array}{l}\text { Indonesian } \\
\text { Text) }\end{array}$ \\
\hline $\begin{array}{l}\text {...reducing its } \\
\text { dependence }\end{array}$ & $\begin{array}{l}\text {...mengurangi } \\
\text { ketergantungan } \\
\text { government } \\
\text { terhadap obligasi } \\
\text { amount of investment } \\
\text { in government } \\
\text { bonds... }\end{array}$ \\
\hline
\end{tabular}

The above sentence shows that the word 'bond' was translated into 'obligasi'. The English dictionary defines 'bond' as '(FINANCE) certificate promising repayment of debt: a certificate issued by the government or a company promising to pay back borrowed money at a fixed rate of interest on a specified date' and 'obligasi' as 'surat pinjaman dengan bunga teirtentu dari pemerintah yang dapat diperjualbelikan'. Here it can be seen clearly that this term, the English banking terms and the translated version, have the same meaning. The translator translates the term 'bonds' into 'obligasi' as it is. The meaning of 'bonds' can be directly found in the dictionary as 'obligasi'. The use of Literal Procedure to translate this term is clearly shown because the translator is producing a receptor language equivalent and it use word-for-word translation and the form has not changed so as the meaning. Thus, the use of the procedure did not change the meaning of the word 'bond'.

The translator does not make up the meaning of the original. He discovers it through commonsense study of the language patterns of the original text. The translator understands, as does anyone who has learned more than one language, that every language expresses its ideas in different 
ways. The translator understands that much of what we say in any language is figurative, that is, nonliteral. If we translate figurative language literally, we have not preserved the true meaning of the original. Some people feel that we should translate literally, then use footnotes or a commentary or a trained person alongside the translation, to explain what the real meaning is behind the literalisms of the translation. But this is not true translation, since true translation allows the user of the translation to understand the original meaning, just as the users of the original text did.

\section{B. Transference}

Table 3. Transference

\begin{tabular}{|l|l|}
\hline English (Source Text) & Indonesian (Target \\
Text)
\end{tabular}

Transference, as the SL word was adopted into TL, the word use become loan word or adoption. The use of transference in translating 'dividend' in the sentence was in accordance with the procedure. The dictionary defines 'dividend' as 'stockholder's share of profit: company profits paid pro rata to stockholders, either in cash or in more shares' and 'dividen' as 'bagian laba atau pendapatan perusahaan yang besarnuya ditetapkan oleh direksi serta disahkan oleh rapat pemegang saham untuk dibagikan kepada pemegang saham'. The use of the procedure on the adoption of word is clearly portrayed in the word 'dividen' because it adopted from the Source Text 'dividend'. There is no equivalent form in the receptor language for the word 'dividend' whatsoever, so new word of 'dividen' is created based on the Source Text.

\section{Naturalization}

Table 4. Naturalization

\begin{tabular}{|l|l|}
\hline English (Source Text) & $\begin{array}{l}\text { Indonesian } \\
\text { Text) }\end{array}$ \\
\hline $\begin{array}{l}\text { Total equity amounted to } \\
\text { Rp 12.63 trillion as at } \\
\text { year-end } 2003, \ldots\end{array}$ & $\begin{array}{l}\text { Total ekuitas pada akhir } \\
\text { triliun,... }\end{array}$ \\
\hline
\end{tabular}

Naturalization, this adapts the SL word first the normal pronunciation, then the normal morphology (word-forms) of TL. The use of Naturalization in translating 'equity' was in appropriate with the procedure. The banking dictionary defines 'equity' as 'part of the value paid for: the value of a piece of property over and above any mortgage or other liabilities relating to it' and 'ekuitas' kepemilikan dibentuk nilai uang'. This kind of procedure did not result in a change in the meaning. Naturalization occurs when there are no equivalence terms or words in the TT that could collocate the terms/words of the ST. The word 'equity' was neutralized into 'ekuitas' in Indonesian language and it have been commonly recognized either by financial profession or common people. The formation of term 'equity' into 'ekuitas' derives from the ST first normal pronunciation. Such formation is not apart from the part of speech of the ST. We can see that both 'equity' and 'ekuitas' have the same part of speech which is as noun. In Indonesia, the Naturalized word/term is usually changed it form to correspond the normal pronunciation, such as 'sasi' in 'globalisasi', 'tas' in 'kualitas', and etc.

\section{Functional Equivalent}

Table 5. Funtional Equivalent

\begin{tabular}{|l|l|}
\hline English (Source Text) & $\begin{array}{l}\text { Indonesian (Target } \\
\text { Text) }\end{array}$ \\
\hline $\begin{array}{l}\text { Interest income from non- } \\
\text { performing loans and }\end{array}$ & $\begin{array}{l}\text { Pendapatan bunga dari } \\
\text { kredit dan aktiva } \\
\text { other productive assets is } \\
\text { produktif lainnya yang } \\
\text { reported as contingent } \\
\text { receivables... }\end{array}$ \\
$\begin{array}{l}\text { diklasifikasikan sebagai } \\
\text { non-performing sebagai } \\
\text { dilaporkan } \\
\text { tagihan kontinjensi... }\end{array}$ \\
\hline
\end{tabular}

Functional Equivalent, it requires the use of culture-free word, sometimes with a new specific term. Moreover, Peter Newmark claims that the functional equivalent is the "most accurate way of translating i.e. deculturalising a cultural word. In the sentence, the term 'contingent receivable' consists of two different words. First is 'contingent' and 'receivable'. The meaning of 'contingent', as referred on Webster dictionary, is 'a group forming a larger group' and 'receivable' is 'money owed: business assets consisting of amounts of money that a company is owed' and 'tagihan' as 'hasil menagih; uang dsb yang harus ditagih' and 'kontijensi' come from the word 'kontingen' which means 'rombongan (olahragawan, pramuka, pasukan militer, dsb) yang dikirim untuk bergabung dengan kelompok yang lebih besar'. The translator translating 'contingent receivable' into 'tagihan kontijensi' not 'tagihan kontingen'. The translator was afraid to translate this word literally to avoid misinterpreting and choose to adopt it with common banking term recognized by the Target reader. By using this procedure, it does not change the meaning because the use of term 'tagihan kontijensi' is already recognized by the Target 
reader although 'kontijensi' is not found in Kamus Besar Bahasa Indonesia.

\section{E. Descriptive Equivalent}

Table 6. Descriptive Equivalent

\begin{tabular}{|l|l|}
\hline English (Source Text) & $\begin{array}{l}\text { Indonesian } \\
\text { Text) }\end{array}$ \\
\hline $\begin{array}{l}\text { The capital adequacy } \\
\text { ratio (CAR) of BCA in }\end{array}$ & $\begin{array}{l}\text { Rasio kenyediaan miban } \\
\text { penodal } \\
\text { minimum (CAR) BCA } \\
\text { market risk is 27.95\%. }\end{array}$ \\
& $\begin{array}{l}\text { tahun 2003 setelah } \\
\text { memperhitungkan risiko } \\
\text { pasar adalah sebesar } \\
\end{array}$ \\
& $27,95 \%$. \\
\hline
\end{tabular}

Descriptive Equivalent, it is used to translate culturally-bound words or expression that are not found in TL culture but considered important in text. In accordance to the previous sentence, this sentence is also consist of multi-word in one term, 'capital', 'adequacy', and 'ratio'. The meaning of each word are respectively 'capital' as 'cash for investment: money that can be used to produce further wealth', 'adequacy' as 'enough: sufficient in quality or quantity to meet a need', and 'ratio' as 'proportional relationship: a proportional relationship between two different numbers or quantities. The translator translates the term into 'rasio kewajiban penyediaan modal minimum' and not 'rasio modal adekuat'. If we trace the meaning word-for-word, the meaning of 'rasio' is 'hubungan taraf atau bilangan antara dua hal yang mirip; perbandingan antara berbagai gejala yang dapat dinyatakan dengan angka; nisbah. 'modal' as 'uang yang digunakan sebaga pokok untuk berdagang; harta benda yang dapat digunakan untuk menambah kekayaan, and 'adekuat' memenuhi syarat, mamadai; sama harkatnya. The translator chose to translate it into 'rasio kewajiban penyediaan modal minimum' because the term 'rasio modal adekuat' is not recognized as a valid baking term although, if we trace it word-for-word, it has the same meaning with 'capital adequacy ratio'. The translator also adds some new word to explain more about the true meaning of such term. While in the phrase 'Legal Lending Limit' was translated into 'Batas Maksimum Pemberian Kredit', the translator adding new word of 'Kredit' to provide additional information so that the reader will obtain the true meaning of the Source Text. The use of the procedure is appropriate and it does affect the meaning.

\section{F. Synonym}

Table 7. Synonym

\begin{tabular}{|l|lr|}
\hline English (Source Text) & $\begin{array}{l}\text { Indonesian } \\
\text { Text) }\end{array}$ & (Target \\
\hline $\begin{array}{l}\text { Earnings per share } \\
\text { based on net operating } \\
\text { income in 2003... }\end{array}$ & $\begin{array}{l}\text { Laba per saham } \\
\text { berdasarkan laba } \\
\text { operasional bersih pada } \\
\text { tahun 2003... }\end{array}$ \\
\hline
\end{tabular}

Synonym, this procedure is used to SL word where there is no clear one-to-one equivalent, and the word is not important in the text. In the sentence, the term 'Earnings per share' was translated into 'Laba per saham'. The banking dictionary defines 'earnings' as 'money earned: money earned, either through paid employment, as profit, or from investments' and 'Laba' as 'keuntungan (yang diperoleh dengan menjual barang lebih tinggi dari pembeliannya, pembuangan uang, dsb). In this matter, the translator did not translated 'Earnings' into 'Laba-laba' because he feels that it would disrupt the equivalence and it would mislead the reader because 'Laba'laba' renders to an eight-legged insect although such procedure is justifiable. By using this procedure, it does not change the meaning because both 'Earnings' and 'Laba' have the same meaning respectively, which is 'money earned: money earned, either through paid employment, as profit, or from investments'.

\section{G. Shift or Transposition}

Table 8. Shift or Transposition

\begin{tabular}{|l|lr|}
\hline English (Source Text) & $\begin{array}{l}\text { Indonesian } \\
\text { Text) }\end{array}$ \\
\hline $\begin{array}{l}\text { The Extraordinary } \\
\text { General Shareholders' }\end{array}$ & $\begin{array}{l}\text { Rapat } \\
\text { Pemegang Saham Luar }\end{array}$ \\
Meeting on 12 April & $\begin{array}{l}\text { Biasa tanggal 12 April } \\
\text { 2001.. }\end{array}$ & $2001 \ldots$ \\
\hline
\end{tabular}

Shift or Transposition, it is a translation procedure involving a change in the grammar from $\mathrm{SL}$ to TL. In the sentence, the term 'The Extraordinary General Shareholders' Meeting' was translated into 'Rapat Umum Pemegang Saham Luar Biasa'. In this matter, the translator use the procedure of shift and transposition appropriately because if we trace the SL text it would be translated into 'Rapat Pemegang Saham Umum Luar Biasa' but the translator rather to choose 'Rapat Umum Pemegang Saham Luar Biasa' due to such term in equivalent in Indonesia. It also applied in the second example, 'debtor'. The translator changed the structure of the word and translated it into 'debtornya'. It is clearly shown that the translator transposes the form of the word structure from SL into TL equivalence. Therefore, the translated text sounded natural while the meaning did not changed. 


\section{H. Reduction}

Table 9. Reduction

\begin{tabular}{|l|lr|}
\hline English (Source Text) & Indonesian & (Target \\
& Text) & \\
\hline ALCO then decides the & ALCO r remudian \\
pricing strategy for & menentukan r rtrategi \\
the interest rate on & penetapan tingkat \\
deposits and loans by & bunga simpanan dan \\
taking into consideration & kredit berdasarkan \\
current circumstances & kondisi dan persaingan \\
and competition. & di pasar. \\
\hline
\end{tabular}

Reduction and Expansion, there are relatively imprecise translation procedure, which practice intuitively in some cases. This procedure occurs in a formal circumstance, which requires translator's intuition based on naturalness, accuracy, and clarity. In the sentence, the term 'interest rate on deposits' was translated into 'tingkat bunga simpanan'. This is one of the reduction examples where 'tingkat bunga simpanan' is the Indonesian equivalent which is adopted from the English term. The translator did not translate the word 'on' because it might not sound natural and he chooses to omit the word 'on', yet the meaning is not changed. This entails translating in a transparent, fluent, invisible style in order to minimize the foreignness of the TT. It seems that the translator want to leave the reader in peace, as much as possible, and he should move the author/original ST toward him.

\section{Expansion}

Table 10. Expansion

\begin{tabular}{|l|lr|}
\hline English (Source Text) & Indonesian & (Target \\
& Text) & \\
\hline ...was in accordance & sesuai rengan \\
with the tentative income & perhitungan pajak \\
tax calculation, with & sementara, dengan \\
calculation of taxable & perhitungan laba kena \\
income is as follows: & pajak sebagai berikut: \\
\hline
\end{tabular}

Reduction and Expansion, there are relatively imprecise translation procedure, which practice intuitively in some cases. In the sentence, the term 'taxable income' was translated into 'laba kena pajak'. In this matter, the translator used expansion. 'laba kena pajak' is the Indonesian equivalent which is adopted from English equivalent. The translator add the word 'kena' to emphasize the meaning of 'taxable' and it match the Indonesian equivalent of the term 'taxable income'. The meaning of the term is not changed.

\section{J. Equivalence and Adaptation}

Table 11. Equivalance and Adaptation

\begin{tabular}{|l|l|}
\hline English (Source Text) & Indonesian (Target \\
Text)
\end{tabular}

Equivalence and Adaptation, Equivalence is the accounting for the same situation in different terms; Adaptation is a recognized equivalent between two situations. An adaptation, also known as a free translation, is a translation procedure whereby the translator replaces a social, or cultural, reality in the source text with a corresponding reality in the target text; this new reality would be more usual to the audience of the target text. In the sentence, the term 'demand deposits' was translated into 'giro'. In this matter, the translator translate 'demand deposits' into 'giro' for the sake of equivalencies, because 'giro' is in equivalent to the word 'demand deposits'. Both word have the same meaning where respectively 'demand deposits' means 'immediately withdrawable deposit: a bank deposit that can be withdrawn at any time without notice' and 'giro' means 'simpanan pada bank yang penarikannya dapat dilakukan setiap saat dengan menggunakan cek atau surat perintah 'pembayaran lain atau dengan cara pemindahbukuan'. In this procedure, something specific to the source language culture is expressed in a totally different way that is familiar or appropriate to the target language culture. This is where the translator "travel" from one given structure or approach to reality in the Source Language into other structures or approaches in the Target Language.

\section{A. Couplets}

Table 12. Couplets

\begin{tabular}{|l|lr|}
\hline English (Source Text) & $\begin{array}{l}\text { Indonesian } \\
\text { Text) }\end{array}$ \\
\hline $\begin{array}{l}\text {..as part of the } \\
\text { divestment of shares }\end{array}$ & $\begin{array}{l}\text {..sebagai bagian dari } \\
\text { divestasi pemilikan }\end{array}$ \\
$\begin{array}{l}\text { owned by the Republic } \\
\text { of Indonesia represented } \\
\text { sy BPPN. }\end{array}$ & $\begin{array}{l}\text { Indonesia yang diwakili } \\
\text { oleh BPPN. }\end{array}$ \\
\hline
\end{tabular}

Couplets, this is a combination of two or more translation procedures for dealing with a single problem. In the sentence, the term 'divestment of shares' was translated into 'divestasi pemilikan saham'. There are two procedures occurred in translating the term, Naturalization and Descriptive Translation. Naturalization is occurred when translating 'divestment' (take away from somebody: to take away something, especially status or power, from somebody or something (often passive)) into 'divestasi' (pelepasam; pembebasan; pengurangan modal) and Descriptive 
Translation was occurred when translating 'shares' (part of company's stock: any of the equal, usually small, parts into which a company's capital stock is divided) into 'pemilikan saham' where the translator add new word in the Target Text that is 'pemilikan' in front of 'saham' (hak yang dimiliki oleh pemegang saham terhadap perusahaan berkat penyerahan bagian modal sehingga dianggap berbagi pemilikan dan pengawasan) to describe more about the meaning of 'divestment of shares' so that the target reader can not mistranslate the term. It seems that translator put the reader into his priority, it shown from the TL term which is important from the TL literature, although it may not be sufficiently well known. Considering these definitions and examining thoroughly the glossary, there is no such a translation meeting these criteria available.

\section{CONCLUSION}

This study aims at analyzing and deciding banking term empirical data concerning the procedure that is commonly used in translating banking term in legal document documents and whether the translation of Indonesian banking terms in legal documents affect the meaning. In line with the research question: "What are the procedures applied in translating banking terminology in legal documents?" it can be concluded that the procedures in translating banking terminology were not entirely applied as there are some characteristics that did not meet the qualification.

As far as the translation is concerned, different types of translation procedures were introduced and it was taken from Peter Newmark's books A Textbook of Translation and Approaches to Translation. Though these procedures in particular were determined to be used while translating cultural words of which terminology is a part of, it was proved that not all these procedures would be productive in translating banking terminology in legal document. This may come from the fact that the field of study, i. e. banking, is so specific that recognized translation or cultural and functional equivalents were employed most often.

After thoroughly analyzing the banking terminology in legal document, the writers only found ten out of eighteen procedures of Peter Newmark applied in translating banking terminology in legal document. The procedures are; (1) Literal Translation (34.02\%), (2) Transference (26.5\%), (3) Naturalization (8.1\%), (4) Functional Equivalent (3.0\%), (5) Descriptive Equivalent (10.2\%), (6) Synonym (3.0\%), (7) Shift or
Transposition (4.0\%), (8) Reduction and Expansion (5.1\%), (9) Equivalence and Adaptation (1.0\%), (10) Couplets $(2.0 \%)$

From the data above, we can clearly see the procedure that occurred frequently is Literal Translation $(34.02 \%)$ since equivalent terms were found in dictionaries, in secondary sources and in parallel texts. The second procedures were Transference (26.5\%) and followed by (5) Descriptive Equivalent (10.2\%), by the use of a natural word or phrase describing the term or explaining its function. It indicates that Literal Translation is the most compatible since to be used in translating specific translation.

The main focus is being to preserve the meaning of the text. Some of the changes were obligatory due to grammatical conventions and structures of the TL while others were optional for various reasons. However, the most important factors to consider in the process of translation are to bear in mind the purpose of the text, the target reader, which it reads naturally in the target language and, above all, that it preserves the meaning of the source text. The result of the study showed that the procedure apparently did not change the meaning.

Peter Newmark's procedures found in translating banking terms in legal document are mostly Literal Translation. It indicates that Literal Translation is the most compatible to be used in translating specific translation. By conveying these findings, the writer is expected to improve the knowledge in understanding legal studies and give wider insight upon translating specific translation. In addition, to be able to translate a term, one should master the certain language, in this matter banking language. It should be noted that the most important factors to consider in the process of translation are to bear in mind the purpose of the text, the target reader, which it reads naturally in the target language and, above all, that it preserves the meaning of the source text. It seems necessary for a translator to 'spoil' the reader with the context already known by the reader. Also, it is important to put a high priority to the reader by comforting and guiding them. It is not a must if a translator tries producing the same (or at least similar) effects on the TT readers as those created by the original work on its readers.

In studying the translation of banking terms in legal document, various aspects need to be involved. Here, the writer only focused on the way the banking terms were translated. The writer also recommended that further research on translating banking terms could involve the aspect of terminology, such as the semantic, morphological, or the phonological aspect of terminology. In 
conducting this kind of research, the writer suggests using a latest specific dictionary, as since language keeps evolved, in order to help in understanding the exact meaning of some terms. By having a complete dictionary, it will make it easier for those who are interested in conducting a research on specific translation. Also learning the structure of both English and Indonesian language is crucial in creating a meaningful and useful translation.

\section{REFERENCES}

Amalia, F. (2006). Idiologi dalam Penerjemahan. May, 58.

Baker, M. (2001). Literary translation, practices. Routledge Encyclopedia of Translation Studies.

Cain, G. (2009). Cambridge advanced learner's dictionary [Book Review]. The English Australia Journal.

David Crystal. (2016). English as A Global Language. In The Palgrave Handbook of Economics and Language. https://doi.org/10.1007/978-1-137-32505-1

Hatim, B., \& Munday, J. (2013). Translation An Advanced Resource Book. In Journal of Chemical Information and Modeling (Vol. 53, Issue 9). https://doi.org/10.1017/CBO9781107415324. 004

Ilha do Desterro 28, 1992, pp 169-170. (1992). 169-170.

Kela, R. (2008). Hatim, B \& Mason, I Discourse and the Translator London: Longman, 1990. Hatim, B \& Mason, I Discourse and the Translator London: Longman, 1990. Ilha Do Desterro.

McElvenny, J. (2013). Ogden and Richards' The meaning of meaning and early analytic philosophy. Language Sciences, 41(PB), 212-221.

https://doi.org/10.1016/j.langsci.2013.10.001

Merriam-Webster's collegiate dictionary. (2004). Choice Reviews Online. https://doi.org/10.5860/choice.41-2515

Nida 1914-2011, E. A. (Eugene A. (1969). The theory and practice of translation / by Eugene A. Nida and Charles R. Taber (C. R. Taber (Ed.)). E. J. Brill.

Nida, E. A., Dil, A. S., \& Linguistic Research
Group of, P. (1975). Language structure and translation : essays. In Language science and national development.

Niederbäumer, A. (2000). German Terminology of Banking: Linguistic Methods of Description and Implementation of a Program for Term Extraction. November.

Šarcevic, S. (1999). Legal Translation and Translation Theory: a Receiver-oriented Approach. La Traduction Juridique Histoire Théories et Pratique, 1-13. http://tradulex.org/Actes2000/sarcevic.pdf

Schäffner, C. (1993). Peter Newmark. About Translation . TargetTarget International Journal of Translation Studies. https://doi.org/10.1075/target.5.2.11sch

The_Bilingual_LSP_Dictionary. (n.d.).

Verity, D. P., \& Larson, M. L. (1986). MeaningBased Translation: A Guide to CrossLanguage Equivalence. The Modern Language Journal. https://doi.org/10.2307/328112

Widyastuti, K., Nababan, M. R., \& Djatmika, D. (2017). KAJIAN KUALITAS TERJEMAHAN TINDAK TUTUR YANG MENGANDUNG IMPLIKATUR PADA FILM THE PIRATES OF CARIBBEAN: THE CURSE OF THE BLACK PEARL (2003), DEAD MAN CHEST (2006), DAN AT THE WORLD'S END (2007): Sebuah Kajian Terjemahan dengan Pendekatan Pragmatik. PRASASTI: Journal of Linguistics. https://doi.org/10.20961/prasasti.v2i2.2304 